\title{
Subtyping of polyposis nasi: phenotypes, endotypes and comorbidities
}

\author{
Michael Koennecke · Ludger Klimek · Joaquim Mullol · Philippe Gevaert · Barbara Wollenberg
}

Received: 26 July 2017 / Accepted: 12 October 2017 / Published online: 22 January 2018

(c) The Author(s) 2018. This article is an open access publication.

\begin{abstract}
Background Chronic rhinosinusitis (CRS) is a heterogeneous, multifactorial inflammatory disease of the nasal and paranasal mucosa. It has not been possible to date to develop an internationally standardized, uniform classification for this disorder. A phenotype classification according to CRS with (CRSwNP) and without polyposis (CRSsNP) is usually made. However, a large number of studies have shown that there are also different endotypes of CRS within these phenotypes, with different pathophysiologies of chronic inflammation of the nasal mucosa. This review describes the central immunological processes in nasal polyps, as well as the impact of related diseases on the inflammatory profile of nasal polyps.

Materials and methods The current knowledge on the immunological and molecular processes of CRS, in particular CRSwNP and its classification into specific endotypes, was put together by means of a structured literature search in Medline, PubMed, the national and international guideline registers, and the Cochrane Library.
\end{abstract}

Dr. M. Koennecke $(\triangle) \cdot$ B. Wollenberg

Lübeck Campus, Department of Otorhinolaryngology,

University Hospital Schleswig-Holstein, Ratzeburger

Allee 160, 23538 Lübeck, Germany

michael.koennecke@uksh.de

L. Klimek

Center for Rhinology and Allergology, Wiesbaden, Germany

J. Mullol

Rhinology Unit and Smell Clinic, Department of

Otorhinolaryngology, Hospital Clinic, IDIBAPS, University of

Barcelona, Barcelona, CIBERES, Spain

P. Gevaert

Department of Otorhinolaryngology, Ghent University, Ghent, Belgium

gium
Results Based on the current literature, the different immunological processes in CRS and nasal polyps were elaborated and a graphical representation in the form of an immunological network developed. In addition, different inflammatory profiles can be found in CRSwNP depending on related diseases, such as bronchial asthma, cystic fibrosis (CF), or NASID-Exacerbated Respiratory Disease (N-ERD).

Conclusion The identification of different endotypes of CRSwNP may help to improve diagnostics and develop novel individual treatment approaches in CRSwNP.

Keywords Chronic rhinosinusitis - Nasal polyps · CRSwNP $\cdot$ Asthma $\cdot$ N-ERD

$\begin{array}{ll}\text { Abbreviations } \\ \text { AFRS } & \text { Allergic fungal rhinosinusitis } \\ \text { AIS } & \text { Aspirin-intolerance syndrome } \\ \text { AFS } & \text { Allergic fungal sinusitis } \\ \text { AScA } & \text { Asthmatic sinusitis with allergy } \\ \text { ASsA } & \text { Asthmatic sinusitis without allergy } \\ \text { BCA } & \text { B cell-attracting chemokine } \\ \text { CD } & \text { Cluster of differentiation } \\ \text { CF } & \text { Cystic fibrosis } \\ \text { CFTR } & \text { Cystic fibrosis transmembrane conduc- } \\ & \text { tance regulator protein } \\ \text { CRS } & \text { Chronic rhinosinusitis } \\ \text { CRSsNP } & \text { Chronic rhinosinusitis without nasal } \\ & \text { polyps } \\ \text { CRSwNP } & \text { Chronic rhinosinusitis with nasal polyps } \\ \text { CCL } & \text { CC motif chemokine ligand } \\ \text { CCR } & \text { CC motif chemokine receptor } \\ \text { CXCL } & \text { CXC motif chemokine ligand } \\ \text { CXCR } & \text { CXC motif chemokine receptor } \\ \text { ECP } & \text { Eosinophilic cationic protein } \\ \text { EFRS } & \text { Eosinophilic fungal rhinosinusitis } \\ \text { IgA } & \text { Immunoglobulin A }\end{array}$

AScA Asthmatic sinusitis with allergy

ASsA Asthmatic sinusitis without allergy

BCA B cell-attracting chemokine

Cluster of differentiation

Cystic fibrosis 


$\begin{array}{ll}\text { IgE } & \text { Immunoglobulin E } \\ \text { IFN } & \text { Interferon } \\ \text { IL } & \text { Interleukin } \\ \text { ILC } & \text { Innate lymphoid cells } \\ \text { MPO } & \text { Myeloperoxidase } \\ \text { NAScA } & \text { Non-asthmatic sinusitis with allergy } \\ \text { N-ERD } & \text { NASID-exacerbated respiratory disease } \\ \text { SDF } & \text { Stromal cell-derived factor } \\ \text { TFH } & \text { Follicular helper T cells } \\ \text { Th } & \text { T helper } \\ \text { TNF } & \text { Tumor necrosis factor } \\ \text { TNSS } & \text { Total nasal symptom score } \\ \text { TSLP } & \text { Thymic stromal lymphopoietin }\end{array}$

\section{Introduction}

Chronic rhinosinusitis (CRS) affects approximately $5-15 \%$ of the European and American population, making it a widespread health problem that creates significant costs for health systems and national economies [1, 2]. Clinically, CRS (with or without nasal polyps) in adults is defined as the presence of two or more symptoms one of which should be either nasal blockage/obstruction/congestion or nasal discharge (anterior/posterior nasal drip), \pm reduction or loss of smell, \pm facial pain/pressure, for more than 12 weeks $[1,3]$. Secondary symptoms such as headache, fever, halitosis, cough, toothache, drowsiness, or ear pressure may also be present. More recent US and European guidelines require-in addition to two main criteria-endoscopic and/or radiological evidence of inflammatory tissue [1, 4]. Based on endoscopic examinations of the nasal cavity or imaging procedures, CRS can be differentiated into chronic rhinosinusitis with nasal polyps (CRSwNP) and chronic rhinosinusitis without nasal polyps (CRSsNP). This classification is referred to as phenotype classification.

There is currently increasing evidence to suggest that there are numerous endotypes of CRS, with different pathophysiologies and different forms of inflammation within the phenotypes CRSwNP and CRSsNP. This is particularly true for CRSwNP, which affects approximately $1-4 \%$ of the general population [1].

Histologically, nasal polyps are pale gray, edematous, sometimes also fibrous, stalked protrusions that develop in the middle nasal passage, the ethmoid bone, and the middle nasal turbinate [5]. For reasons as yet unknown, the lower nasal turbinate does not tend to form polyps [6-9]. Nasal polyps can be divided into at least four groups according to histological criteria [10-12]. At a frequency of $65-90 \%$, edematous, eosinophilic polyps are the most common form of nasal polyps [9, 12]. Further differentiation of CRSwNP phenotypes may help to develop new therapeutic strategies that are tailored to the respective classification.

However, the partially overlapping histological features do not always permit precise classification into a certain type. Against this background, there is also a discussion about whether histological examinations could be influenced by different preoperative medications [12]. Therefore, it is currently unclear how differing therapies for the clinical treatment of nasal polyps can be determined on the basis of these classifications. For this reason, reliable and easy-to-determine biomarkers beyond classical histology would be highly desirable and could significantly improve diagnostics. However, these are not available as yet [13].

All forms of CRS appear to be caused by inflammatory changes in the sinonasal mucosa. A Th2mediated inflammatory process is usually found in CRSwNP, whereas both Th2- and Th1-mediated processes are found in CRSsNP [1]. However, this subdivision is an over-generalization and is by no means found consistently, which is why the latest findings in this regard are described in more detail below.

\section{Immunology of nasal polyps}

In recent years, the $\mathrm{T}$ cell subpopulations in chronic sinusitis and nasal polyposis have been well characterized and their biological function determined.

$\mathrm{CD}^{+} \mathrm{T}$ cells are able to differentiate into, e.g., T helper cells (Th)1, Th2, Th9, Th17, Th22, and follicular $\mathrm{T}$ helper (TFH) effector cells [14, 15]. The balance between these $\mathrm{T}$ helper subtypes is extremely important for the physiology of the mucosal immune system and can be altered by persistent inflammatory processes. Eosinophilic, Th2-dominated cell infiltration is usually seen in CRSwNP [1]. The inflammatory process is characterized by interleukin (IL)-4-, IL-5- and IL-13-producing Th2 cells, as well as eosinophilic cationic protein (ECP) and eotaxin-1/ $-2 /-3[16,17]$. Each of these cyto- and chemokines has specific functions. IL-4 is a mediator and modulator of the immune and inflammatory response and is mainly produced by Th2 cells. In addition, IL- 4 is able to promote the differentiation of $\mathrm{CD}^{+} \mathrm{T}$ cells into Th2 cells and at the same time inhibit interferon (IFN) $-\gamma$ production and Th1 response [18, 19]. It was shown only recently that upregulation of IL-4 occurs in nasal polyps, whereas IFN- $\gamma$ expression is reduced, and that IFN- $\gamma$ levels do not differ significantly between nasal polyps and control tissue [17, 20, 21]. IL-5 is the most important eosinophilic activating cytokine and promotes the survival of mature eosinophils in tissue [22, 23]. IL-5 is upregulated in nasal polyps [24] and plays an important role in the pathogenesis of nasal polyps. ECP and eotaxin promote the attraction and activation of eosinophils and are also upregulated in nasal polyps [16, 17, 25].

IL-6 is a proinflammatory cytokine capable of inhibiting neutrophil recruitment [26-28] and was also found to be upregulated in CRSwNP [29, 30]. However, the differing data on regulatory molecules of the IL-6 signaling pathway do not answer the question 
of whether the IL-6 signaling pathway is part of the pathogenesis of CRSwNP.

Keswani and colleagues [31], as well as Cho et al. [32], found elevated expression of IL-32 in whole tissue extracts from nasal polyps. IL-32 is also described as a proinflammatory cytokine [33-38], which appears to play a role in various inflammatory disorders such as chronic obstructive pulmonary disease (COPD) and atopic dermatitis [39, 40]. Nine different isoforms of IL-32 are now known, although their functional differences remain unclear [34, 41]. Further studies are required to assess the role of IL-32 in nasal polyps in patients with chronic rhinosinusitis.

IL-25 and IL-33 are other cytokines that are produced in sinonasal epithelial cells and which promote Th2 inflammation in CRSwNP [42-44]. IL-25 is upregulated in nasal polyps and increases thymic stromal lymphopoietin (TSLP)-induced Th2 cell expansion $[45,46]$. Increased expression of TSLP in the epithelium of patients with CRSwNP has already been demonstrated [47-49]. This is an IL-7-like cytokine. This effectively activates mast cells in combination with IL-1 to produce in turn Th2 cytokines, including IL-5 and IL-13 [50]. A study from Baltimore (MA, USA) showed that the sinonasal epithelial cells of patients with untreated CRSwNP show increased basal expression of IL-33 compared with sinonasal epithelial cells in patients with CRSwNP following treatment with methylprednisolone [51]. This increased expression of IL-33 in untreated polyps was confirmed by another working group [52]. IL-33 is a chemoattractant for Th2 cells and promotes the production of Th2 cytokines such as IL-4, IL-5, and IL-13. Epithelial cells of the respiratory tract are able to produce IL-33; its receptor is expressed by, e.g., eosinophils and Th2 lymphocytes [53]. IL-33 plays an important role in maintaining Th2-mediated eosinophilic inflammation [54]. Thus, polymorphisms within the IL-33 receptor gene, the interleukin-1 receptor-like 1 (IL1RL1) gene, correlate with CRS severity [55]. It is assumed that IL-25 and IL-33 are able to establish the link between epithelial cells and the Th2 response [42]; however, this needs to be investigated further.

On the other hand, the cytokines IL-25, IL-33, and TSLP have an effect on type 2 innate lymphoid cells (ILC2) [56]. These are lymphocyte-like cells that do not express any allergen-specific T cell receptors. ILCs are considered to be counterparts of Th2 cells, since both produce cytokines such as IL-5 and IL-13 [57], meaning that ILC2 activated by IL-33 and IL-25 can induce eosinophilic respiratory tract inflammation [58, 59]. ILC2 are abundant in nasal polyps and are associated with an increased number of eosinophils in the blood and tissue of patients with CRSwNP and a clinically relevant worsening of total nasal symptom score (TNSS) and asthma comorbidity $[60,61]$.

In addition to eotaxin-1/-2/-3, various chemokines, such as CC motif chemokine ligand 5 (CCL5 or RANTES), CXC motif chemokine ligand 8 (CXCL8 or IL-8), CCL23, CCL18, CXCL12 (stromal cell-derived factor $1 \alpha$, SDF-1 $\alpha$ ), and CXCL13 (B cell-attracting chemokine 1, BCA-1), have been linked to the selective recruitment of inflammatory cells in the mucosa in CRSwNP. RANTES was one of the first identified chemokines found to be upregulated in nasal polyps $[62,63]$. RANTES is a member of the CC chemokine family and a strong chemoattractant for eosinophils and T-lymphocytes, but not for neutrophils, and is primarily secreted by nasal epithelial cells [62, 64, 65]. RANTES is also expressed and secreted in nasal polyps. Interestingly, nasal polyps with a high number of eosinophils exhibit significantly increased RANTES gene and protein expression. Consequently, increased RANTES expression results in an increased number of eosinophils in tissue. Therefore, RANTES likely also plays an important role in the mobilization of eosinophils in nasal polyps.

CXCL8 (IL-8), which attracts neutrophils and eosinophils into the nasal mucosa, provided these have been previously activated by IL-5, plays a further role in nasal polyp inflammation [66]. IL-8, however, is considered more of an unspecific marker for CRSwNP. Although altered levels of IL-8 were identified in nasal polyps [30, 66-69], upregulation does not correlate significantly with the formation of nasal polyps [66].

Poposki and colleagues [70] were able to show strong production of CCL23 in nasal polyps, which was largely colocalized with ECP, indicating predominantly eosinophilic CCL23 production in nasal polyps. CCL23 is a chemoattractant for monocytes, dendritic cells, and lymphocytes, and it has been shown that CCL23 induces endothelial cell migration via the CC motif chemokine receptor CCR1, which is also upregulated in nasal polyps [70-73]. It has been shown for Th2 cytokines such as IL-4 and IL-13 that these induce CCL23 expression in monocytes [74].

In addition, significantly increased CCL18-mRNA expression was found in nasal polyps and the inferior tubinates [75]. M2 macrophages and mast cells were identified in CRSwNP that express CCL18, which can be induced by the Th2 cytokines IL4-, IL-13, and IL-10 [75]. Since the related receptor CCR8 was only recently identified, the role of CCL18 in the pathogenesis of CRSwNP has not yet been investigated in detail [76]. However, this discovery will help clarify the role of CLL18 in CRSwNP.

Both B cells and the antibody fractions IgA and IgE were found to be elevated in patients with CRSwNP $[77,78]$. B cells express IgA, which triggers the degranulation of eosinophils and represents a possible link to CRSwNP [77]. In this context, it was shown that the chemokines CXCL12 (SDF-1 $\alpha$ ) and CXCL13 (BCA1) are present at elevated levels in nasal polyps. Both attract B cells. Furthermore, the receptors for SDF$1 \alpha$ (CXCR4 and CXCR7) and BCA-1 (CXCR5) are also present at elevated levels [79]. Consequently, the expression of SDF- $1 \alpha$ and BCA-1 in nasal polyps could be important for the recruitment and maintenance of 


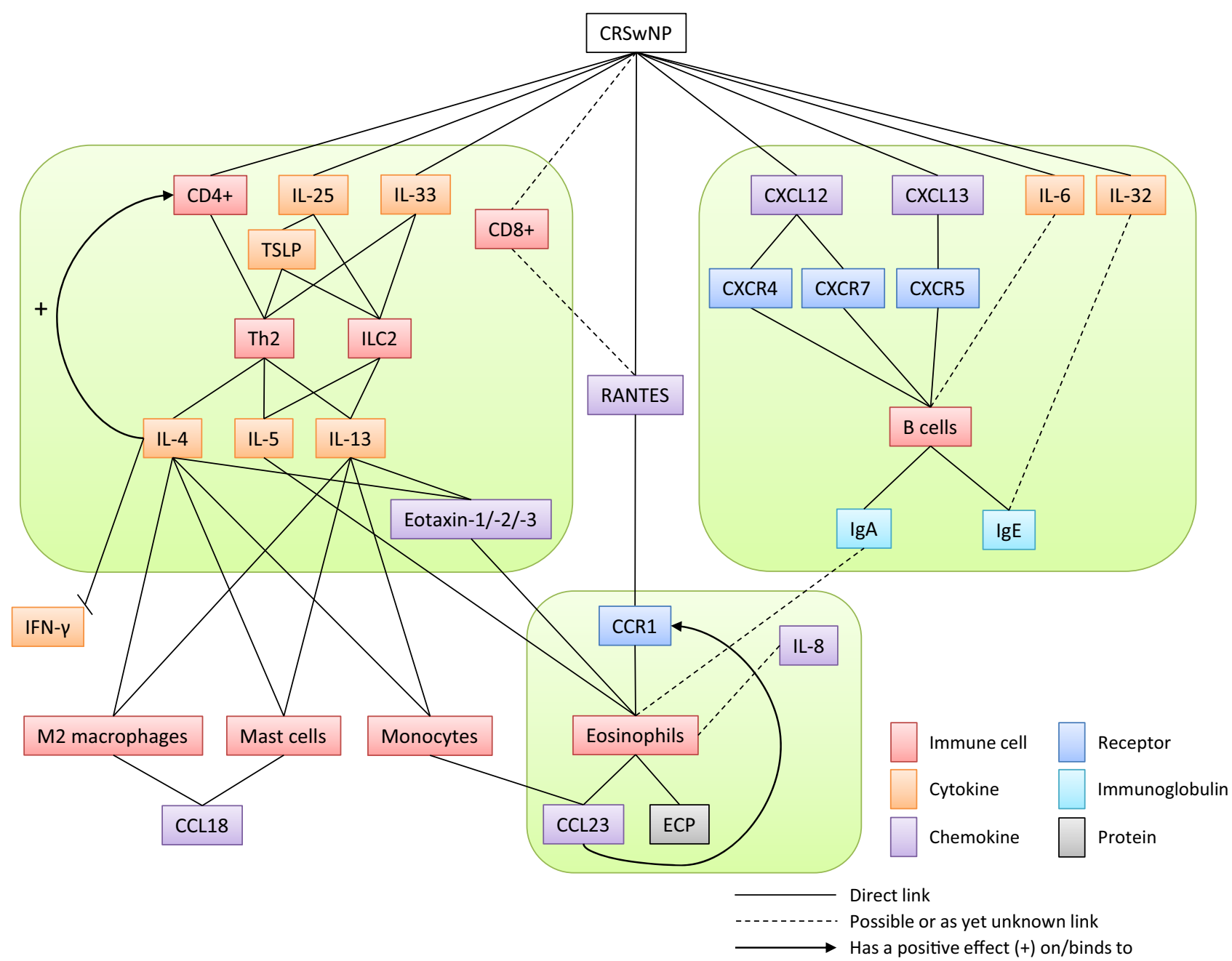

Fig. 1 The immunological processes in nasal polyps. CRSwNP can be divided into three different endotypes: the $\mathrm{T}$ cell-/Th2 cytokine-based endotype, the B cell-/lgEbased endotype, and the eosinophil-based endotype. This gives rise to different treatment approaches in CRSwNP. $C R S w N P$ chronic rhinosinusitis with nasal polyps; $C D$ clus-

B cells. In addition, the increased IgA levels imply an important role for B cells in the pathogenesis of CRSwNP.

Immunological processes are complex and involve a multitude of cell types and proteins. Fig. 1 shows the immunological processes known in nasal polyps.

\section{Phenotypes of CRS}

For some time now, CRS has been divided into different entities. The likely simplest classification into CRSsNP and CRSwNP is based on endoscopic or rhinoscopic findings.

\section{Comorbidities of CRS}

Another traditional classification of CRS is based on its association with other diseases, e.g., the comorbidity of CRSwNP with cystic fibrosis (CF), aspirin in-

ter of differentiation; IL interleukin; TSLP thymic stromal lymphopoietin; Th T-helper; ILC innate lymphoid cell; CXCL CXC motif chemokine ligand; $C X C R$ CXC motif chemokine receptor; Ig immunoglobulin; IFN interferon; CCR CC motif chemokine receptor; CCL CC motif chemokine ligand

tolerance syndrome (AIS) or NASID-Exacerbated Respiratory Disease (N-ERD), inhalation allergies, immunodeficiency syndromes, allergic fungal sinusitis, Wegener's granulomatosis, and bronchial asthma [1].

With regard to CF, nasal polyps are present in approximately $40 \%$ of these patients [80]. These polyps show a more neutrophilic inflammation pattern with overexpression of IL-1 $\beta$, IL-8, IL-21, myeloperoxidase (MPO), and IL-17-producing Th17 cells [17, 20, 81]. As part of this, IL-1 $\beta$ and IL-17 mediate T cell differentiation towards a Th17 phenotype [82]. CF is caused by a defect in the transport of chloride and bicarbonate (cystic fibrosis transmembrane conductance regulator protein, CFTR) [83, 84]. To diagnose CF, chloride sweat tests (the sweat of CF patients contains more than $60 \mathrm{mmol} / \mathrm{l}$ chloride, or in the case of newborns, over $90 \mathrm{mmol} / \mathrm{l}$ chloride) and molecular genetic screening methods, among others, are performed [83, 84]. 
The prevalence of N-ERD among patients with CRSwNP is approximately $16 \%$, while, conversely, up to $96 \%$ of N-ERD patients have nasal polyposis [1, 9]; therefore, a direct pathophysiological link between N-ERD and nasal polyps has been discussed for some time. The cytokine profile of nasal polyps in N-ERD patients shows the typical components of a Th2 disease, as well as eosinophilia and significant upregulation of IL-4 and IL-5 [85]. In addition, significantly increased CCL23 expression is seen in nasal polyps in patients with N-ERD [70]. However, the most striking feature is the increased IFN$\gamma$-expression of eosinophils [85], which is typically associated with Th1 inflammation. To verify the suspected diagnosis of N-ERD, oral provocation testing is considered the gold standard alongside bronchial and nasal provocation tests [86-88]. Research is underway into the development of reliable in vitro laboratory techniques as a diagnostic alternative to provocation testing [87-89]. All laboratory chemical tests to date have been based on detecting the impaired arachidonic acid metabolism in this disease [87-90].

The influence of inhalation allergies on the pathogenesis of nasal polyps is the subject of controversy [1]. In particular, the high prevalence of allergic diseases in the European population makes direct correlations challenging [91]. A study by Perić and colleagues in 2012 [92] investigated the influence of allergies in patients with nasal polyps. This study involving 30 patients-13 with allergies, 17 without allergies-investigated the cytokine and chemokine levels in nasal secretions. The concentrations of IL4 , IL-5, IL-6, and tumor necrosis factor (TNF)- $\beta$ were significantly higher in allergic patients compared with non-allergic patients. In addition, the number of eosinophils in nasal polyps was significantly higher in allergic patients compared with the non-allergic group. Moreover, it has been shown that both IL-6 and the Th2 cytokines IL-4 and IL-5 are more strongly expressed in patients with allergic rhinitis [93, 94]. Interestingly, IL-6 was more highly expressed in nasal polyps in allergic individuals than in nasal polyps in non-allergic individuals [92, 95], suggesting that IL-6 and the IL- 6 signaling pathway could play a potential role in CRSwNP in patients with inhalation allergies. Furthermore, studies on the pathogenesis of nasal polyps have not demonstrated a link to elevated TNF$\beta$ as yet. Also known as lymphotoxin (LT), TNF- $\beta$ is produced by Th1 cells, in addition to IFN- $\gamma$ and TNF$\alpha$, and promotes cellular inflammation [96]. As such, TNF- $\beta$ may be a potential marker for allergic nasal polyps alongside IL-6.

Immunodeficiencies on the humoral and cellular levels have also been associated with CRSsNP and CRSwNP [97-100]. Defects in the production or function of IgA and IgG immunoglobulins, cellular effects at the B cell level, T cells, neutrophils/monocytes, and complement defects play an important role here [97-100].
The prevalence of allergic fungal rhinosinusitis (AFRS) or eosinophilic fungal rhinosinusitis (EFRS) in patients with nasal polyposis is about 9-12\% [101, 102] and shows Th2-mediated inflammation with varying levels of Th2 cytokines [103]. AFRS-/EFRS-related nasal polyps exhibit a significantly higher level of IgE and IL-5. However, further investigations are needed to assess the role of AFRS/EFRS in the pathogenesis of CRSwNP, since the so-called "fungal hypothesis" as the cause of CRSwNP can be considered disproved [1].

Furthermore, specific forms of CRS have been described in sarcoidosis, Wegener's granulomatosis, congenital or acquired disorders of mucociliary clearance and/or ciliary activity, as well as Churg-Strauss syndrome [1, 100, 104].

Bronchial asthma is particularly frequently associated with CRSwNP: approximately $40 \%$ of patients with CRSwNP also suffer from bronchial asthma [9]; conversely, around $7 \%$ of asthma patients have nasal polyps [1]. However, the correlation between asthma and CRSwNP is poorly understood as yet. In a 2013 study, nasal secretions from 40 patients with nasal polyps (20 with and 20 without asthma) were investigated for cytokine expression [105]. IL-5, IL-6, and IL-10 levels were significantly increased in asthmatic patients with nasal polyps compared with non-asthmatic patients with nasal polyps. However, it is not possible to say with any certainty at present that this alteration can be attributed to the correlation with asthma. Another study by Nabavi and colleagues [106] found no differences in the serum expression of IL-4, IL-13, and IFN- $\gamma$ between asthmatic patients with CRSwNP and non-asthmatic patients with CRSwNP. However, increased IgE levels were found. To date, IL-5 and IgE were identified as indicators for patients with CRSwNP and additional asthma [107]. Only recently, Tomassen and colleagues were able to show that there is a correlation between clinical characteristics and inflammatory endotypes of CRS. Results showed that patients with high IL-5 levels had the highest prevalence of nasal polyps and asthma. In contrast, patients with low IL-5 levels were primarily classified as CRSsNP. Thus, the prevalence of asthma increases significantly depending on this endotype classification in patients with CRSwNP. IL-5 remains the main factor determining the phenotype with nasal polyps and asthma, thereby gaining in importance as a therapeutic target [30].

\section{Endotypes of CRS}

Four distinct endotypes of CRSwNP, albeit it with clearly overlapping characteristics, have been defined in a classification scheme [108] in a current review article on endotype-based subtyping of CRSwNP:

- T cell-/Th2 cytokine-based endotype

- Eosinophil-based endotype 


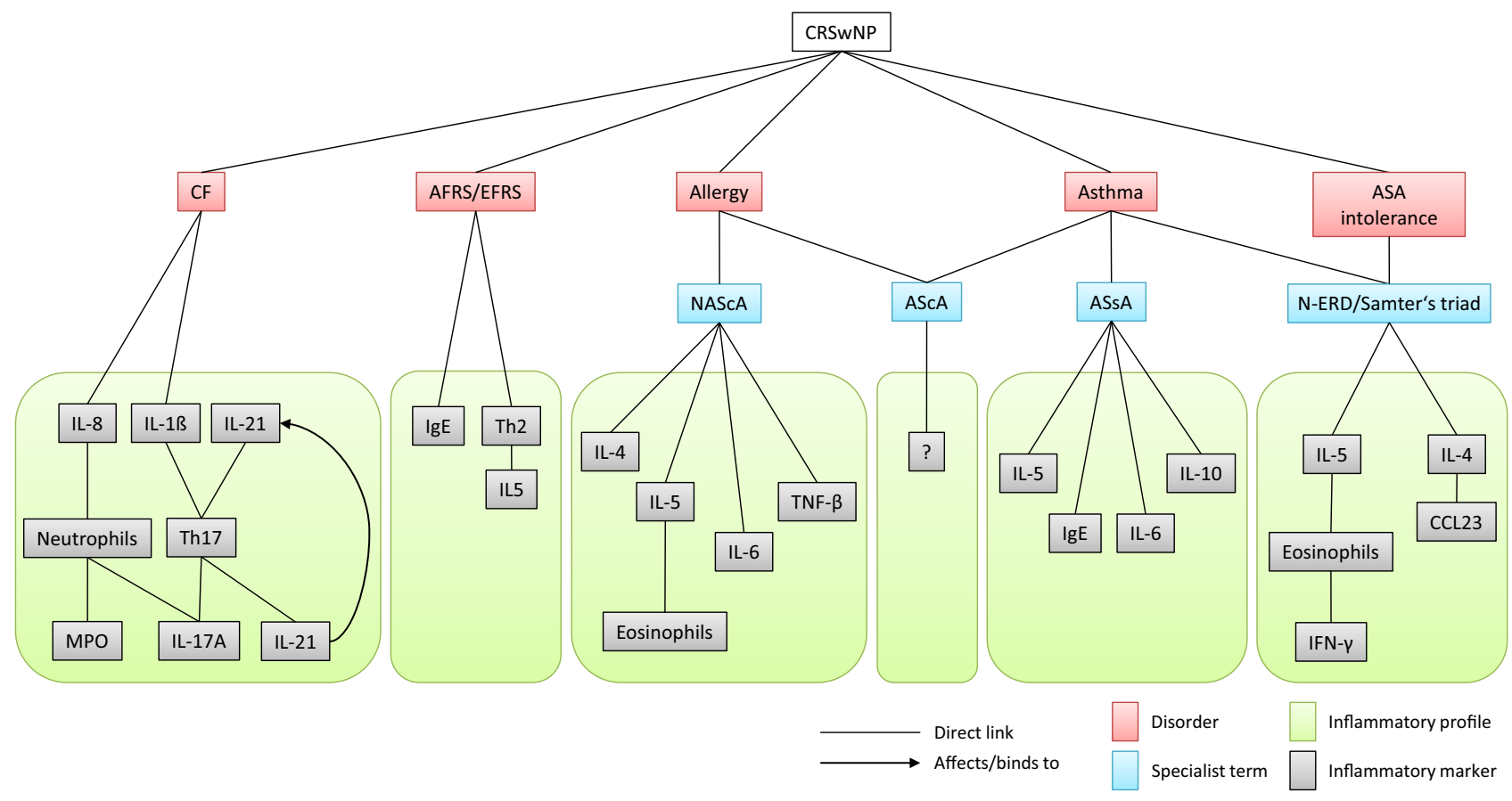

Fig. 2 The affect of various comorbidities of CRSwNP on the inflammatory profile in nasal polyps: different comorbidities of CRSwNP affect the development of endotypes of nasal polyps. As a result, the classic inflammatory profile in nasal polyps shifts and gains additional specific markers. When associated with cystic fibrosis, the inflammatory profile of nasal polyps changes extensively. CRSWNP chronic rhinosinusitis with nasal polyps; $C F$ cystic fibrosis; AFRS allergic

- B cell-/IgE-based endotype

- Cysteinyl-based endotype

\section{Endotypes of CRS with various comorbidities}

The various comorbidities of CRSwNP affect endotype expression and the associated inflammatory profile of nasal polyps (Fig. 2). Therefore, the diagnosis of comorbidities should be included in endotype classification. This requirement has not been taken into consideration in previous publications on endotype classification in CRSwNP and could represent an important step on the way to personalized medicine or precision medicine in CRSwNP.

\section{Novel treatment approaches based on endotype classification}

Endotype classification gives rise to a number of novel treatment approaches in CRSwNP, e.g., the use of biologics such as dupilumab (anti-IL-4/13), mepolizumab (anti-IL-5), or omalizumab (anti-IgE) [109, 110].

These newly emerging therapies are aimed at a specific pathophysiological signaling pathway. However, careful selection of the patient population is required to successfully implement such endotype- fungal rhinosinusitis; EFRS eosinophilic fungal rhinosinusitis; $N A S c A$ non-asthmatic sinusitis with allergy; $A S c A$ asthmatic sinusitis with allergy; $A S s A$ asthmatic sinusitis without allergy; $N$-ERD NASID-Exacerbated Respiratory Disease; IL interleukin; Th T-helper; MPO myeloperoxidase; Ig immunoglobulin; TNF tumor necrosis factor; CCL CC motif chemokine ligand

based treatment approaches. Positive treatment outcomes have already been demonstrated in CRSwNP with the above-mentioned monoclonal antibodies against IgE, IL-5, and IL-4/13 [111].

To date, however, only a selected patient collective has benefited from these developments. More precise endotype classification of patients could potentially help to optimize treatments. A discussion will be required, for example, as to whether treatment directed against a specific endotype is sufficient for certain patient populations or whether combination therapy might be necessary.

With regard to possible applications in the routine treatment of CRS patients, it is essential to mention here that there are no approved preparations for the indications CRS and CRSwNP. Therefore, treatment performed outside clinical trials has usually been carried out in patients receiving these substances for other indications or as individual treatment attempts in the form of off-label therapy.

\section{Conclusion}

CRS is a heterogeneous group of inflammatory disorders of the nasal and paranasal sinus mucosa. In clinical routine, the disorder continues to be subdivided into CRSsNP and CRSwNP on the basis of phenological characteristics. 
However, there is no doubt that there are multifactorial pathophysiologies for CRSwNP in particular. These different endotypes have different signaling pathways, from the process of initiation of inflammation, its maintenance, and its chronification to tissue alteration. In addition to the "classic" CRSwNP endotype of Th2-based and eosinophil-dominated inflammation, there are other endotypes that suggest different therapeutic approaches [111].

Hitherto, endotype classifications have neglected the fact that disorders associated with CRSwNP may point to the endotype and the typical inflammatory pattern that ensues. These should therefore be included in new classifications to be developed in the future.

Against this background, topical nasal glucocorticosteroids will remain the basic treatment in CRS and surgical approaches will continue to be indispensable. However, the addition of endotype-based individualized treatments with potential biologicals to these "basic treatment options" could help to put into effect the principle of "personalized medicine" in CRS in the future.

Conflict of interest M. Koennecke, L. Klimek, Joaquim Mullol, P. Gevaert and B. Wollenberg declare that they have no competing interests.

Open Access This article is distributed under the terms of the Creative Commons Attribution 4.0 International License (http://creativecommons.org/licenses/by/4.0/), which permits unrestricted use, distribution, and reproduction in any medium, provided you give appropriate credit to the original author(s) and the source, provide a link to the Creative Commons license, and indicate if changes were made.

\section{References}

1. Fokkens WJ, Lund VJ, Mullol J, Bachert C, Alobid I, Baroody F, et al. European position paper on rhinosinusitis and nasal polyps 2012. Rhinol Suppl. 2012;23:1-298.

2. Hastan D, Fokkens WJ, Bachert C, Newson RB, Bislimovska J, Bockelbrink A, et al. Chronic rhinosinusitis in Europe-an underestimated disease. AGA ${ }^{2}$ LEN study. Allergy. 2011;66:1216-23.

3. Lanza DC, Kennedy DW. Adult rhinosinusitis defined. Otolaryngol Head NeckSurg. 1997;117:S1-S7.

4. Rosenfeld RM. Clinical practice guideline on adult sinusitis. Otolaryngol Head NeckSurg. 2007;137:365-77.

5. Settipane RA, Peters AT, Chiu AG. Chapter 6: nasal polyps. Am J Rhinol Allergy. 2013;27(Suppl 1):S20-S5.

6. Landis BN, Konnerth CG, Hummel T. A study on the frequency of olfactory dysfunction. Laryngoscope. 2004;114:1764-9.

7. Messerklinger W. Background and evolution of endoscopic sinus surgery. Ear Nose Throat J. 1994;73:449-50.

8. Stammberger H. The evolution of functional endoscopic sinus surgery. Ear Nose Throat J. 1994;73(451):454-5.

9. Stuck BA, Bachert C, Federspil P, Hosemann W, Klimek L, Mosges R, et al. Rhinosinusitis guidelines of the German Society for Otorhinolaryngology, Head and Neck Surgery. HNO. 2007;55:758-77. pages 758-60, 762-4,766-77.

10. Hellquist HB. Nasal polyps update. Histopathology. Allergy Asthma Proc. 1996;17:237-42.
11. Davidsson A, Hellquist HB. The so-called 'allergic' nasal polyp. Orl J Otorhinolaryngol RelatSpec. 1993;55:30-5.

12. Couto LG, Fernades AM, Brandão DF, de Santi Neto D, Valera FC, Anselmo-Lima WT. Histological aspects of rhinosinusal polyps. BrazJ Otorhinolaryngol. 2008;74:207-12.

13. Calus L, Van Zele T, Derycke L, Krysko O, Dutre T, Tomassen P, et al. Local inflammation in chronic upper airway disease. CurrPharmDes. 2012;18:2336-46.

14. Annunziato F, Romagnani S. Heterogeneity of human effector CD4+ T cells. Arthritis Res Ther. 2009;11:257.

15. Zygmunt B, Veldhoen M. T helper cell differentiation more than just cytokines. Adv Immunol. 2011;109:159-96.

16. Plager DA, Kahl JC, Asmann YW, Nilson AE, Pallanch JF, Friedman O, et al. Gene transcription changes in asthmatic chronic rhinosinusitis with nasal polyps and comparison to those in atopic dermatitis. PLoS ONE. 2010;5:e11450.

17. Van Zele T, Claeys S, Gevaert P, Van Maele G, Holtappels G, Van Cauwenberge P, et al. Differentiation of chronic sinus diseases bymeasurement ofinflammatorymediators. Allergy. 2006;61:1280-9.

18. Kopf M, Le Gros G, Bachmann M, Lamers MC, Bluethmann H, Köhler G. Disruption of the murine IL-4 gene blocks Th2 cytokine responses. Nature. 1993;362:245-8.

19. Ouyang W, Ranganath SH, Weindel K, Bhattacharya D, Murphy TL, Sha WC, et al. Inhibition of Th1 development mediated by GATA-3 through an IL-4-independent mechanism. Immunity. 1998;9:745-55.

20. Derycke L, Eyerich S, Van Crombruggen K, Pérez-Novo C, Holtappels G, Deruyck N, et al. Mixed T helper cell signatures in chronic rhinosinusitis with and without polyps. PLoSONE. 2014;9:e97581.

21. Danielsen A, Tynning T, Brokstad KA, Olofsson J, Davidsson A. Interleukin 5, IL6, IL12, IFN-gamma, RANTES and Fractalkine in human nasal polyps, turbinate mucosa and serum. Eur Arch Otorhinolaryngol. 2006;263:282-9.

22. Li Z, Zhang Y, Sun B. Current understanding of Th2 cell differentiation and function. Protein Cell. 2011;2:604-11.

23. Prussin C, Yin Y, Upadhyaya B. T(H)2 heterogeneity: Does function follow form? J Allergy Clin Immunol. 2010;126:1094-8.

24. Bachert C, Wagenmann M, Hauser U, Rudack C. IL-5 synthesis is upregulated in human nasal polyp tissue. JAllergy Clin Immunol. 1997;99:837-42.

25. Bachert C, Gevaert P, Holtappels G, Cuvelier C, van Cauwenberge P. Nasal polyposis: from cytokines to growth. Am J Rhinol. 2000;14:279-90.

26. Hurst SM, Wilkinson TS, McLoughlin RM, Jones S, Horiuchi S, Yamamoto N, et al. Il-6 and its soluble receptor orchestrate a temporal switch in the pattern of leukocyte recruitment seen during acute inflammation. Immunity. 2001;14:705-14.

27. Jones SA. Directing transition from innate to acquired immunity: defining a role for IL-6. J Immunol. 2005;175:3463-8.

28. Kaplanski G, Marin V, Montero-Julian F, Mantovani A, Farnarier C. IL-6: a regulator of the transition from neutrophil to monocyte recruitment during inflammation. Trends Immunol. 2003;24:25-9.

29. Peters AT, Kato A, Zhang N, Conley DB, Suh L, Tancowny B, et al. Evidence for altered activity of the IL- 6 pathway in chronic rhinosinusitis with nasal polyps. J Allergy Clin Immunol. 2010;125:397-403.e10.

30. Tomassen P, Vandeplas G, Van Zele T, Cardell LO, Arebro J, Olze $\mathrm{H}$, et al. Inflammatory endotypes of chronic rhinosinusitis based on cluster analysis of biomarkers. J Allergy Clin Immunol. 2016;137:1449-1456.e4. 
31. Keswani A, Chustz RT, Suh L, Carter R, Peters AT, Tan BK, et al. Differential expression of interleukin-32 in chronic rhinosinusitis with and without nasal polyps. Allergy. 2012;67:25-32.

32. Cho JS, Kim JA, Park JH, Park IH, Han IH, Lee HM. Toll-like receptor 4-mediated expression of interleukin-32 via the c-Jun $\mathrm{N}$-terminal kinase/protein kinase B/cyclic adenosine monophosphate response element binding protein pathway in chronic rhinosinusitis with nasal polyps. Int Forum Allergy Rhinol. 2016;6:1020-8.

33. Bai X, Kim SH, Azam T, McGibney MT, Huang H, Dinarello CA, et al. IL-32 is a host protective cytokine against mycobacterium tuberculosis in differentiated THP-1 human macrophages. J Immunol. 2010;184:3830-40.

34. Dinarello CA, Kim SH. IL-32, a novel cytokine with a possible role in disease. Ann Rheum Dis. 2006;65(Suppl3):iii61-iii4.

35. Kim SH, Han SY, Azam T, Yoon DY, Dinarello CA. Interleukin32: a cytokine and inducer of TNFalpha. Immunity. 2005;22:131-42.

36. Li W, Sun W, Liu L, Yang F, Li Y, Chen Y, et al. IL-32: a host proinflammatory factor against influenza viral replication is upregulated by aberrant epigenetic modifications during influenza A virus infection. JImmunol. 2010;185:5056-65.

37. Netea MG, Azam T, Lewis EC, Joosten LA, Wang M, Langenberg $\mathrm{D}$, et al. Mycobacterium tuberculosis induces interleukin-32 production through a caspase-1/IL18/interferon-gamma-dependent mechanism. PLoS Med. 2006;3:e277.

38. Nold MF, Nold-Petry CA, Pott GB, Zepp JA, Saavedra MT, Kim $\mathrm{SH}$, et al. Endogenous IL-32 controls cytokine and HIV-1 production. J Immunol. 2008;181:557-65.

39. Calabrese F, Baraldo S, Bazzan E, Lunardi F, Rea F, Maestrelli $\mathrm{P}$, et al. IL-32, a novel proinflammatory cytokine in chronic obstructive pulmonary disease. Am J Respir Crit Care Med. 2008;178:894-901.

40. Meyer N, Zimmermann M, Bürgler S, Bassin C, Woehrl S, Moritz K, et al. IL-32 is expressed by human primary keratinocytes and modulates keratinocyte apoptosis in atopic dermatitis. J Allergy Clin Immunol. 2010;125:858-865.e10.

41. Kang JW, Park YS, Lee DH, Kim MS, Bak Y, Ham SY, et al. Interaction network mapping among IL-32 isoforms. Biochimie. 2014;101:248-51.

42. Chin D, Harvey RJ. Nasal polyposis: an inflammatory condition requiring effective anti-inflammatory treatment. Curr Opin Otolaryngol Head NeckSurg. 2013;21:23-30.

43. Lam EP, Kariyawasam HH, Rana BM, Durham SR, McKenzie AN, Powell N, et al. IL-25/IL-33-responsive TH2 cells characterize nasal polyps with a default TH17 signature in nasal mucosa. JAllergy Clin Immunol. 2016;137:1514-24.

44. Kato A. Immunopathology of chronic rhinosinusitis. Allergol Int. 2015;64:121-30.

45. Wang $\mathrm{YH}$, Angkasekwinai $\mathrm{P}, \mathrm{Lu} \mathrm{N}$, Voo KS, Arima K, Hanabuchi S, et al. IL-25 augments type 2 immune responses by enhancing the expansion and functions of TSLP-DC-activated Th2 memory cells. J Exp Med. 2007;204:1837-47.

46. Shin HW, Kim DK, Park MH, Eun KM, Lee M, So D, et al. IL-25 as a novel therapeutic target in nasal polyps of patients with chronic rhinosinusitis. J Allergy Clin Immunol. 2015;135:1476-1485.e7.

47. Kimura S, Pawankar R, Mori S, Nonaka M, Masuno S, Yagi $\mathrm{T}$, et al. Increased expression and role of thymic stromal lymphopoietinin nasal polyposis. Allergy Asthma Immunol Res. 2011;3:186-93.

48. Liu T, Li TL, Zhao F, Xie C, Liu AM, Chen X, et al. Role of thymic stromal lymphopoietin in the pathogenesis of nasal polyposis. Am J Med Sci. 2011;341:40-7.
49. Nagarkar DR, Poposki JA, Tan BK, Comeau MR, Peters AT, Hulse KE, et al. Thymic stromal lymphopoietin activity is increased in nasal polyps of patients with chronic rhinosinusitis. JAllergy Clin Immunol. 2013;132:593-600.e12.

50. Nagarkar DR, Poposki JA, Comeau MR, Biyasheva A, Avila PC, Schleimer RP, et al. Airway epithelial cells activate TH2 cytokine production in mast cells through IL-1 and thymic stromal lymphopoietin. J Allergy Clin Immunol. 2012;130:225-232.e4.

51. Reh DD, Wang Y, Ramanathan M Jr., Lane AP. Treatmentrecalcitrant chronic rhinosinusitis with polyps is associated with altered epithelial cell expression of interleukin-33. Am JRhinol Allergy. 2010;24:105-9.

52. Kim DK, Jin HR, Eun KM, Mo JH, Cho SH, Oh S, et al. The role of interleukin-33 in chronic rhinosinusitis. Thorax. 2017;72:63545.

53. Arend WP, Palmer G, Gabay C. IL-1, IL-18, and IL-33 families of cytokines. Immunol Rev. 2008;223:20-38.

54. Cherry WB, Yoon J, Bartemes KR, Iijima K, Kita H. A novel IL-1 family cytokine, IL-33, potently activates human eosinophils. JAllergy Clin Immunol. 2008;121:1484-90.

55. Castano R, Bosse Y, Endam LM, Desrosiers M. Evidence of association of interleukin-1 receptor-like 1 gene polymorphisms with chronic rhinosinusitis. Am J Rhinol Allergy. 2009;23:377-84.

56. Mjösberg JM, Trifari S, Crellin NK, Peters CP, van Drunen CM, Piet B, et al. Human IL-25- and IL-33-responsive type 2 innate lymphoid cells are defined by expression of CRTH2 and CD161. Nat Immunol. 2011;12:1055-62.

57. Robinette ML, Colonna M. Immune modules shared by innate lymphoid cells and T cells. J Allergy Clin Immunol. 2016;138:1243-51.

58. Kim HY, Chang YJ, Subramanian S, Lee HH, Albacker LA, Matangkasombut P, et al. Innate lymphoid cells responding to IL-33 mediate airway hyperreactivity independently of adaptive immunity. J Allergy Clin Immunol. 2012;129:216-227.e1-6.

59. MoritaH, MoroK, KoyasuS. Innatelymphoid cellsin allergic and nonallergic inflammation. J Allergy Clin Immunol. 2016;138:1253-64.

60. Ho J, Bailey M, Zaunders J, Mrad N, Sacks R, Sewell W, et al. Cellular comparison of sinus mucosa vs polyp tissue from a single sinus cavity in chronic rhinosinusitis. Int Forum Allergy Rhinol. 2015;5:14-27.

61. Ho J, Bailey M, Zaunders J, Mrad N, Sacks R, Sewell W, et al. Group 2 innate lymphoid cells (ILC2s) are increased in chronic rhinosinusitis with nasal polyps or eosinophilia. Clin Exp Allergy. 2015;45:394-403.

62. BeckLA, Stellato C, Beall LD, Schall TJ, LeopoldD, BickelCA, et al. Detection of the chemokine RANTES and endothelial adhesion moleculesin nasal polyps. JAllergy Clin Immunol. 1996;98:766-80.

63. Davidsson A, Danielsen A, Viale G, Olofsson J, Dell'Orto P, et al. Positive identification in situ of mRNA expression of IL-6, and IL-12, and the chemotactic cytokine RANTES in patients with chronic sinusitis and polypoid disease. Clinical relevance and relation to allergy. Acta Otolaryngol. 1996;116:604-10.

64. Allen JS, Eisma R, LaFreniere D, Leonard G, Kreutzer D. Characterization of the eosinophil chemokine RANTES in nasal polyps. Ann Otol Rhinol Laryngol. 1998;107:416-20.

65. Meyer JE, Bartels J, Görögh T, Sticherling M, Rudack C, Ross DA, et al. The role of RANTES in nasal polyposis. Am J Rhinol. 2005;19:15-20.

66. Chen YS, Arab SF, Westhofen M, Lorenzen J. Expression of interleukin-5, interleukin-8, and interleukin-10 mRNA in 
the osteomeatal complex in nasal polyposis. Am J Rhinol. 2005;19:117-23.

67. Kostamo K, Sorsa T, Leino M, Tervahartiala T, Alenius $\mathrm{H}$, Richardson $\mathrm{M}$, et al. In vivo relationship between collagenase-2 and interleukin-8 but not tumour necrosis factor-alpha in chronic rhinosinusitis with nasal polyposis. Allergy. 2005;60:1275-9.

68. Scavuzzo MC, Fattori B, Ruffoli R, Rocchi V, Carpi A, Berni $\mathrm{R}$, et al. Inflammatory mediators and eosinophilia in atopic and non-atopic patients with nasal polyposis. Biomed Pharmacother. 2005;59:323-9.

69. WangX, Zhang N, Bo M, Holtappels G, Zheng M, Lou H, etal. Diversity of TH cytokine profiles in patients with chronic rhinosinusitis: a multicenter study in Europe, Asia, and Oceania. JAllergy Clin Immunol. 2016;138:1344-53.

70. Poposki JA, Uzzaman A, Nagarkar DR, Chustz RT, Peters AT, Suh LA, et al. Increased expression of the chemokine CCL23 in eosinophilic chronic rhinosinusitis with nasal polyps. JAllergy Clin Immunol. 2011;128:73-81.e4.

71. Bachert C, Van Cauwenberge PB. Inflammatory mechanisms in chronic sinusitis. Acta Otorhinolaryngol Belg. 1997;51:209-17.

72. FundováP, Funda DP, Kovář D, HolýR, Navara M, TlaskalováHogenová H. Increased expression of chemokine receptors CCR1 and CCR3 in nasal polyps: molecular basis for recruitment of the granulocyte infiltrate. Folia Microbiol (praha). 2013;58:219-24.

73. Patel VP, Kreider BL, Li Y, Li H, Leung K, Salcedo T, et al. Molecular and functional characterization of two novel human C-C chemokines as inhibitors of two distinct classes of myeloid progenitors. JExp Med. 1997;185:1163-72.

74. Novak H, Müller A, Harrer N, Günther C, Carballido JM, Woisetschläger M. CCL23 expression is induced by IL-4 in aSTAT6-dependentfashion. JImmunol. 2007;178:4335-41.

75. Peterson S, Poposki JA, Nagarkar DR, Chustz RT, Peters AT, Suh LA, et al. Increased expression of CC chemokine ligand 18 in patients with chronic rhinosinusitis with nasal polyps. JAllergy Clin Immunol. 2012;129:119-127.e1-9.

76. Islam SA, Ling MF, Leung J, Shreffler WG, Luster AD. Identification of human CCR8 as a CCL18 receptor. J Exp Med. 2013;210:1889-98.

77. Kato A, Peters A, Suh L, Carter R, Harris KE, Chandra R, et al. Evidence of a role for B cell-activating factor of the TNF family in the pathogenesis of chronic rhinosinusitis with nasal polyps. JAllergyClin Immunol. 2008;121(92):1385-1392.e2.

78. Polzehl D, Moeller P, Riechelmann H, Perner S. Distinct features of chronic rhinosinusitis with and without nasal polyps. Allergy. 2006;61:1275-9.

79. Patadia M, Dixon J, Conley D, Chandra R, Peters A, Suh LA, et al. Evaluation of the presence of B-cell attractant chemokines in chronic rhinosinusitis. Am J Rhinol Allergy. 2010;24:11-6.

80. Hadfield PJ, Rowe-Jones JM, Mackay IS. The prevalence of nasal polyps in adults with cystic fibrosis. Clin Otolaryngol Allied Sci. 2000;25:19-22.

81. Derycke L, Zhang N, Holtappels G, Dutré T, Bachert C. IL$17 \mathrm{~A}$ as a regulator of neutrophil survival in nasal polyp disease of patients with and without cystic fibrosis. J Cyst Fibros. 2012;11:193-200.

82. Waite JC, Skokos D. Th17 response and inflammatory autoimmune diseases. Int J Inflam. 2012;2012:1-10.

83. Chaaban MR, Kejner A, Rowe SM, Woodworth BA. Cystic fibrosis chronic rhinosinusitis: a comprehensive review. Am J Rhinol Allergy. 2013;27:387-95.

84. Wentzel JL, Virella-Lowell I, Schlosser RJ, Soler ZM. Quantitative sinonasal symptom assessment in an unselected pediatric population with cystic fibrosis. Am J Rhinol Allergy. 2015;29:357-61.

85. Steinke JW, Liu L, Huyett P, Negri J, Payne SC, Borish L. Prominent role of IFN- $\gamma$ in patients with aspirin-exacerbated respiratory disease. J Allergy Clin Immunol. 2013;132:856-865.e1-3.

86. Kirsche H, Klimek L. ASA-intolerance syndrome and persistent rhinosinusitis: differential diagnosis and treatment. HNO. 2015;63:357-63.

87. Kowalski ML, Makowska JS, Blanca M, Bavbek S, Bochenek G, Bousquet J, et al. Hypersensitivity to nonsteroidal anti-inflammatory drugs (NSAIDs)—classification, diagnosis and management: review of the EAACI/ENDA(\#) and GA2LEN/HANNA. Allergy. 2011;66:818-29.

88. Nizankowska-Mogilnicka E, Bochenek G, Mastalerz L, SwierczynskaM,PicadoC,ScaddingG, etal. EAACI/GA2LEN guideline: aspirin provocation tests for diagnosis of aspirin hypersensitivity. Allergy. 2007;62:1111-8.

89. Dollner R, Hörmann K, Stuck BA, Pfaar O, Klimek L. Invitro-Diagnostik des ASS-Intoleranz-Syndroms (Aspirinexacerbated Respiratory Disease: AERD). Allergologie. 2014;37(1):11-9.

90. Szczeklik A, Sanak M. The broken balance in aspirin hypersensitivity. Eur J Pharmacol. 2006;533:145-55.

91. Kramer MF, Ostertag P, Pfrogner E, Rasp G. Nasal interleukin-5, immunoglobulin E, eosinophilic cationic protein, and solubleintercellular adhesion molecule-1 in chronic sinusitis, allergic rhinitis, and nasal polyposis. Laryngoscope. 2000;110:1056-62.

92. Perić A, Vojvodić D, Vukomanović-Durdevid B. Influence of allergy on clinical, immunological and histological characteristics of nasal polyposis. B-ENT. 2012;8:25-32.

93. Baraniuk JN. Pathogenesis of allergic rhinitis. J Allergy Clin Immunol. 1997;99:S763-S72.

94. Scadding G. Cytokine profiles in allergic rhinitis. Curr Allergy Asthma Rep. 2014;14:435.

95. Shin SH, Ye MK, Kim YH, Kim JK. Role of TLRs in the production of chemical mediators in nasal polyp fibroblasts by fungi. Auris Nasus Larynx. 2016;43:166-70.

96. Feghali CA, Wright TM. Cytokines in acute and chronic inflammation. Front Biosci. 1997;2:d12-d26.

97. Nayan S, Alizadehfar R, Desrosiers M. Humoral primary immunodeficiencies in chronic rhinosinusitis. Curr Allergy Asthma Rep. 2015;15:46.

98. Ocampo CJ, Peters AT. Antibody deficiency in chronic rhinosinusitis: epidemiology and burden of illness. Am J RhinolAllergy. 2013;27:34-8.

99. Schwitzguébel AJ, Jandus P, Lacroix JS, Seebach JD, Harr T. Immunoglobulin deficiency in patients with chronic rhinosinusitis: systematic review of theliterature and metaanalysis. JAllergy Clin Immunol. 2015;136:1523-31.

100. Stevens WW, Lee RJ, Schleimer RP, Cohen NA. Chronic rhinosinusitis pathogenesis. J Allergy Clin Immunol. 2015;136:1442-53.

101. Bakhshaee M, Fereidouni M, Mohajer MN, Majidi MR, Azad FJ, Moghiman T. The prevalence of allergic fungal rhinosinusitis in sinonasal polyposis. Eur Arch Otorhinolaryngol. 2013;270:3095-8.

102. TelmesaniLM. Prevalence of allergic fungal sinusitis among patients with nasal polyps. Ann Saudi Med. 2009;29:212-4.

103. Han JK. Subclassification of chronic rhinosinusitis. Laryngoscope. 2013;123(Suppl2):S15-S27.

104. Nakamaru Y, Takagi D, Suzuki M, Homma A, Morita S, Homma A, et al. Otologic and rhinologic manifestations of eosinophilic granulomatosis with polyangiitis. Audiol Neurootol. 2016;21:45-53. 
105. Perić A, Vojvodić D, Perić AV, Radulović V, Miljanović O. Correlation between cytokine levels in nasal fluid and scored clinical parameters in patients with nasal polyposis. Indian J Otolaryngol Head Neck Surg. 2013;65(Suppl 2):295-300.

106. Nabavi M, Arshi S, Bahrami A, Aryan Z, Bemanian MH, Esmaeilzadeh $\mathrm{H}$, et al. Increased level of interleukin-13, but not interleukin- 4 and interferon- $\gamma$ in chronic rhinosinusitis with nasal polyps. Allergol Immunopathol (Madr). 2014;42:465-71.

107. Bachert C, Zhang N. Chronic rhinosinusitis and asthma: novel understanding of the role of IgE 'above atopy'. Intern Med. 2012;272:133-43.
108. Dennis SK, Lam K, Luong A. A review of classification schemes for chronic rhinosinusitis with nasal polyposis endotypes. Laryngoscope Investig Otolaryngol. 2016;1:130-4.

109. Bachert C, Gevaert P, Hellings P. Biotherapeutics in chronic rhinosinusitis with and without nasal polyps. J Allergy Clin Immunol Pract. 2017; https://doi.org/10.1016/j.jaip.2017. 04.024.

110. Kim DW, Cho SH. Emerging endotypes of chronic rhinosinusitis and its application to precision medicine. Allergy Asthma Immunol Res. 2017;9:299-306.

111. De Greve G, Hellings PW, Fokkens WJ, Pugin B, Steelant B, Seys SF. Endotype-driven treatment in chronic upper airway diseases. Clin Transl Allergy. 2017;7:22. 